\title{
In vitro efficacy of fungitoxicants on the growth of Fusarium oxysporum f.sp.carthami isolates causing wilt of safflower
}

\author{
Sunita J.Waghmare*, P. D. Mahajan, B. B. Chirame and V. V. Datar
}

Plant Pathology Section, College of Agriculture, Pune (M.S.) India

\section{ARITCLE INFO}

Received : 18.03 .2017

Revised : 07.03.2018

Accepted : 15.03 .2018

\section{KEY WORDS :}

Fungicides, Wilt of safflower,

Fusarium oxysporum f.sp. carthami

*Corresponding author:

waghmares358@gmail.com

\begin{abstract}
Fusarium oxysporum f.sp. carthami causes wilt of safflower and results in a considerable yield loss. The efficacy of five fungitoxicant at 1,10,25,50,100,500 and $1000 \mu \mathrm{g} / \mathrm{ml}$ concentrations were tested against nineteen isolates of Fusarium oxysporum f.sp.carthami. As the concentrations of fungitoxicants increased, the per cent inhibition also increased. Carbendazim was best fungicide for inhibiting the growth of Fusarium oxysporum f.sp.carthami followed by Propiconazole, Thiram, Captan and Copper oxychloride. Even $1 \mathrm{~g} / \mathrm{ml}$ of Carbendazim was equal or better than $1000 \mu \mathrm{g} / \mathrm{ml}$ of rest of the fungicides in inhibiting the growth of Fusarium oxysporum f.sp.carthami.
\end{abstract}

How to view point the article : Waghmare, Sunita J., Mahajan, P.D., Chirame, B.B. and Datar, V.V. (2018). In vitro efficacy of fungitoxicants on the growth of Fusarium oxysporum f.sp.carthami isolates causing wilt of safflower. Internat. J. Plant Protec., 11(1) : 39-45, DOI : 10.15740/HAS/ IJPP/11.1/39-45. 